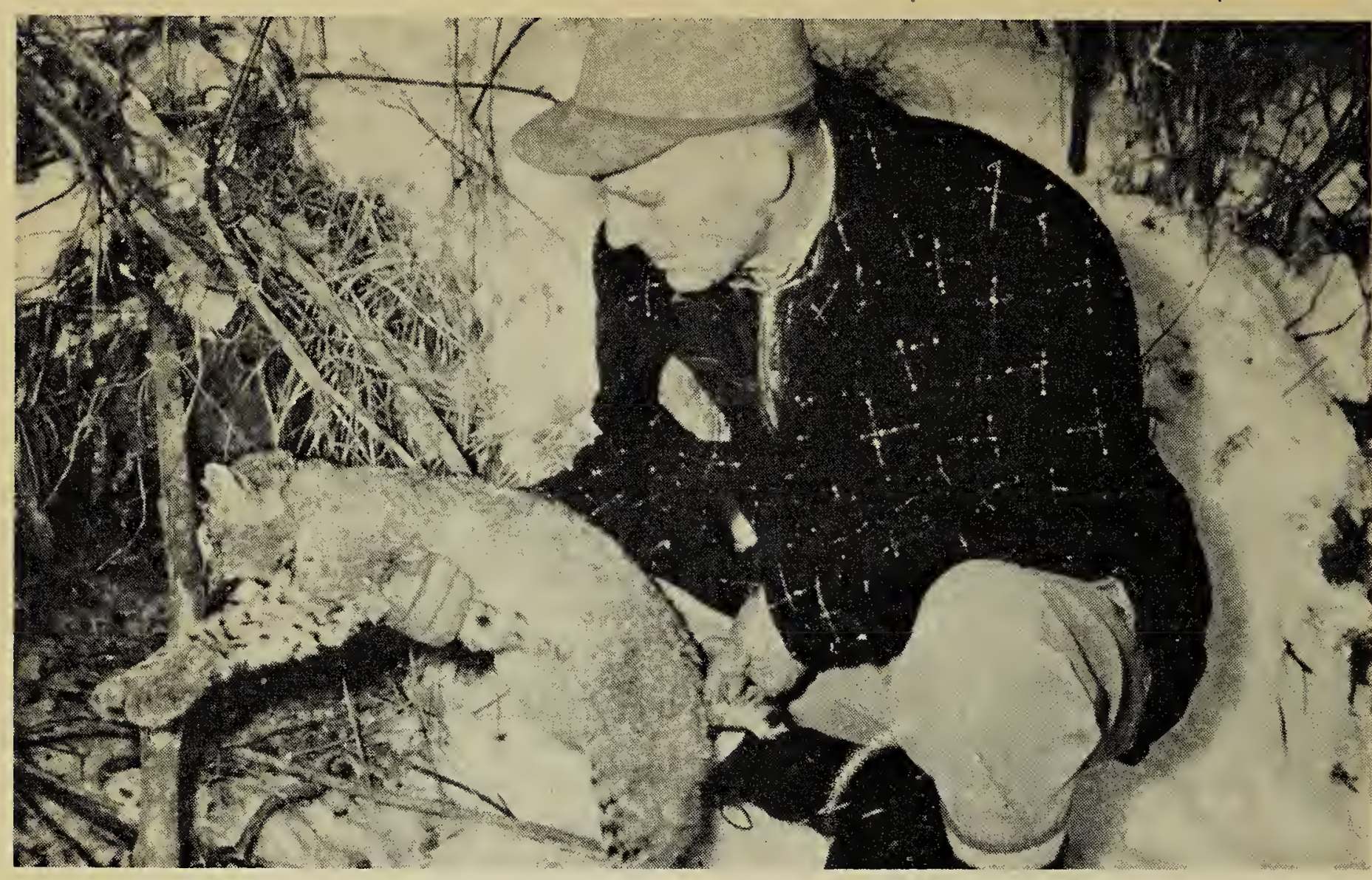

Photo by Doug Gilroy

Albert Swanstion and his Bobcat, Bredin, December 3, 1960.

\section{SECOND BOBCAT COLLECTED NEAR REGINA}

On April 5, 1961, Mr. B. Williamson found a Bobcat caught in a trap which he had seit for Beaver. The Bobcat was reported as being an immature animal, possibly $3 / 4$ grown. The animal was caught in the Boggy Creek Valley about three miles north of the place where Albert Swanston of the museum staff caught his Bobcat (Blue Jay, page 41, March, 1961) which is shown in the photo above. Since these two Bobcats were caught less than five miles from Doug Gilroy's and since a Mountain Lion was also observed in this same area (Blue Joy, page 182, December, 1960) it is little wonder that Doug identifies his farm as being in "the land of the big caits."

Mr: and Mrs. John Hogg of Carnduff have written in to say that Bobcats have been reported seen in their area for about six years now. They are seldom seen but are believed to be fairly common in the area. The banks of the Souris River probably provide a suitable habitat for these animals.-G.F.L.

\section{GRAY SQUIRREL AT OXBOW}

On October 6, 1960, an unusual visitor, a Gray Squirrel, came and he has been seen almost daily until now, January 3, 1961. There are scrub oak along the Souris River near here so I suppose he came from there.

The Gray Squirrel has been seen coming out of a hollow: Manitoba Maple which grows right beside the granaries where he feeds on the grain. We also see him perched precariously at the top of a maple eating seeds. Our little dog delights in chasing him but he just scoots up the side of the bin where he sits with his tail curled elegantly. I don't suppose we'll ever make a pet of him but we would like to.-Mrs. K. D. Paton, Oxbow.

\section{HELPING THE BEAVER}

Last fall we cut some trees in a little ravine a considerable distance from the creek. A beaver had cut some trees in the same area. His trees were just what we wanted so we "limbed" them ready to take away. We did not get back for a couple of days and when we did we found that the beaver had cut the trees inito four foot lengths. I guess he needed them, too. When we saw a beaver out in January, 1961, we wondered if he was our friend of the previous fall.-Mr. and Mrs. John Hogg, Carnduff. 